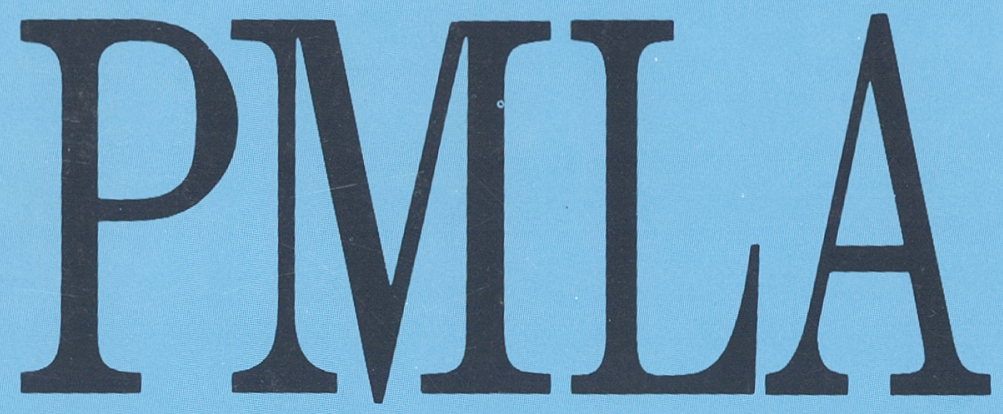

\title{
Publications of the
}

Modern Language

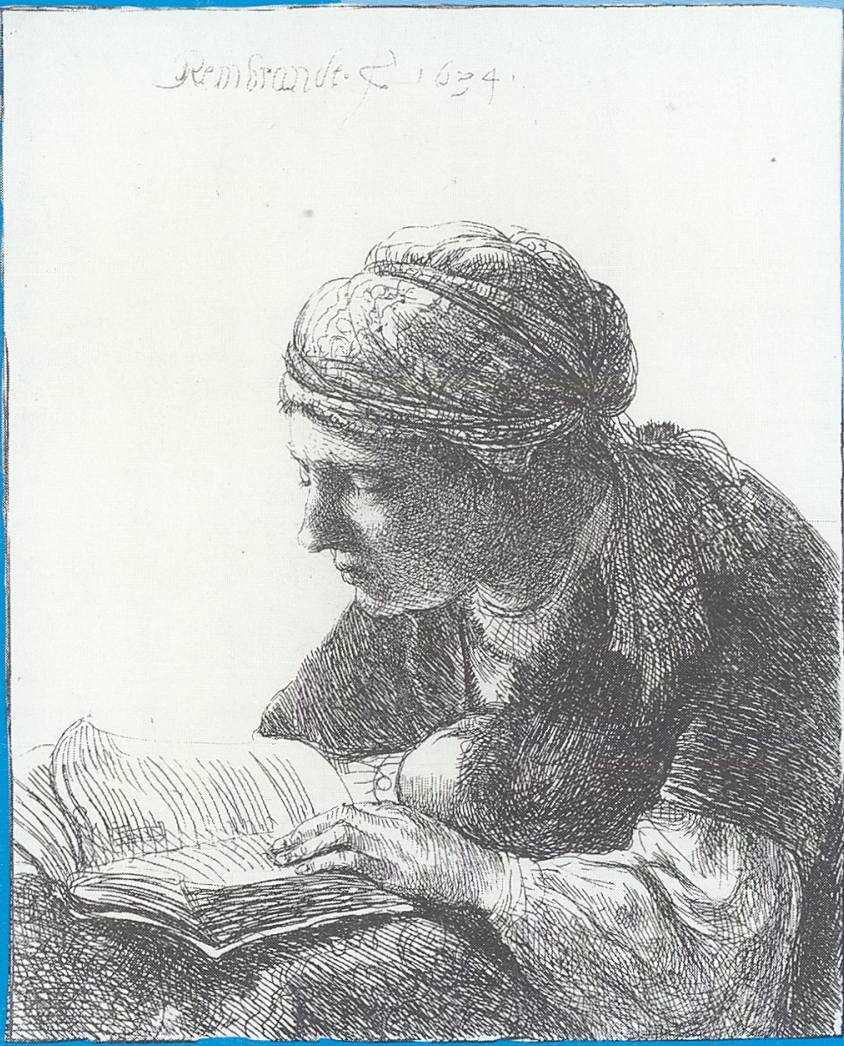

MARCH

Association

of America

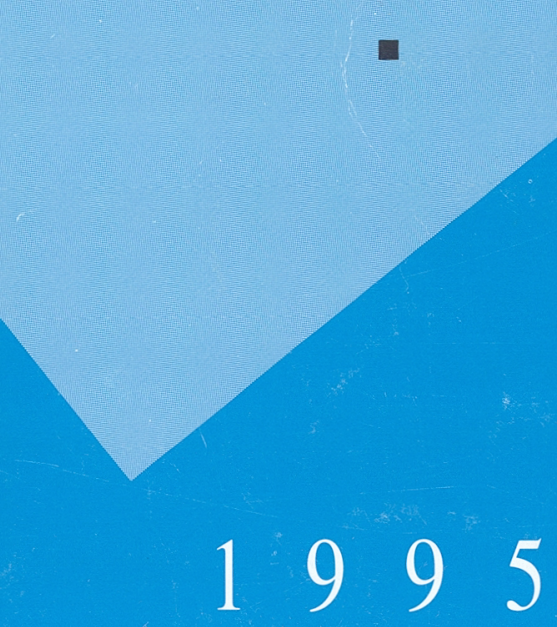

VOLUME 110 口 NUMBER 2 


\section{Goethe: The Collected Woutis}

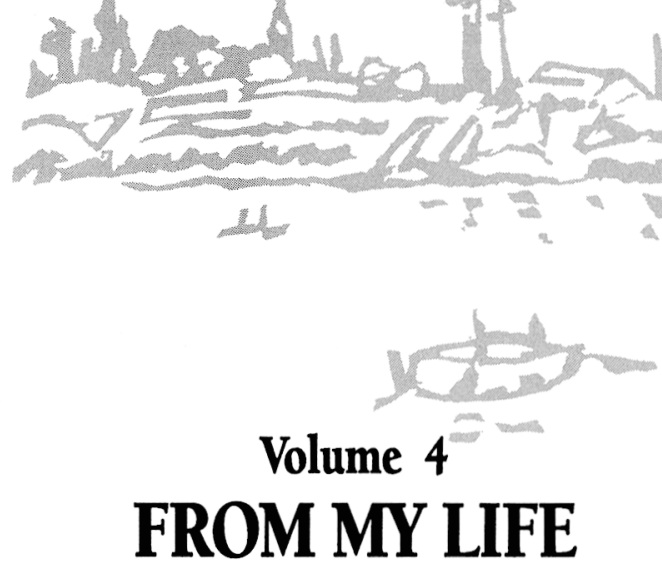

Poetry and Truth (Parts One to Three) Edited by

Thomas P. Saine and Jeffrey L. Sammons

Translated by Robert R. Heitner

Introduction and notes by Thomas P. Saine

Covering the period from his birth in 1749 to his departure for Weimar in 1775, in Poetry and Truth Goethe recalls his childhood and youth as the son of well-to-do, middle-class parents, his education and literary awakening, early loves, and the creation and reception of works from his Sturm und Drang years, such as The Sorrows of Young Werther, Goetz von Berlichingen, and Urfaust. Not merely an account of Goethe's own life, this book also explores the influences on his early years-friends, mentors, famous personages of his time, intellectual movements, cities, and historical events-to draw a lifelike picture of his time. Paper: \$18.95 ISBN 0-691-03797-3

\section{Volume 6}

\section{ITALIAN JOURNEY}

\section{Edited by Thomas P. Saine and Jeffrey L. Sammons}

Translated by Robert R. Heitner Introduction and notes by Thomas P. Saine

Containing the letters and diaries that Goethe wrote during his journey to Italy at age thirty-seven, Italian Journey reveals his tremendous range of interests. His writings cover literature, art history and his own struggle to be a painter, various sciences and political events, personal encounters, and the Italian landscape. For Goethe the writer, this temporal and spiritual journey was at the root of his development from Sturm und Drang to classicism, a decisive point in his life and the history of German literature.

Paper: \$14.95 ISBN 0-691-03799-X Cloth: $\$ 60.00$ ISBN 0-691-02968-1

\section{Volume 5 FROM MY LIFE \\ Edited by Thomas P. Saine and Jeffrey L. Sammons \\ Poetry and Truth (Part Four)}

Translated by Robert $R$. Heitner, notes by Thomas $P$. Saine

\section{Campaign in France 1792 Siege of Mainz}

Translated, with an introduction and notes, by Thomas $P$. Saine

Campaign in France 1792 - Siege of Mainz, Goethe's narrative of the unsuccessful campaign and the siege, has become a classic text for the history of Franco-German relations during the revolutionary period. This is a product of recollection, historical hindsight, and considerable study of other published sources.

Paper: \$14.95 ISBN 0-691-03798-1

Volumes 4 \& 5 cloth set

Cloth: $\$ 95.00$ ISBN 0-691-02967-3

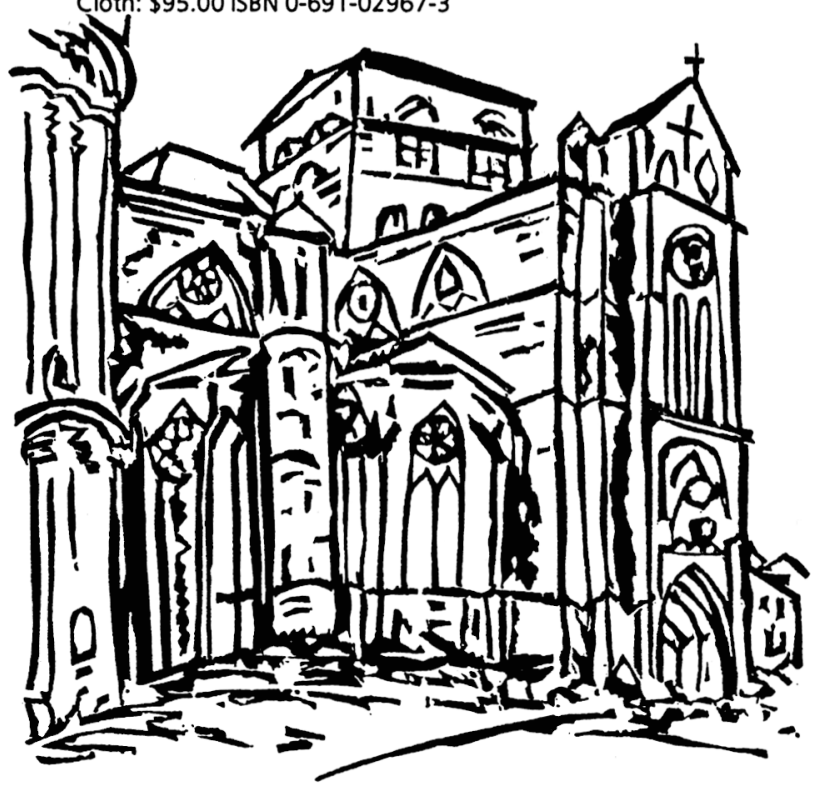




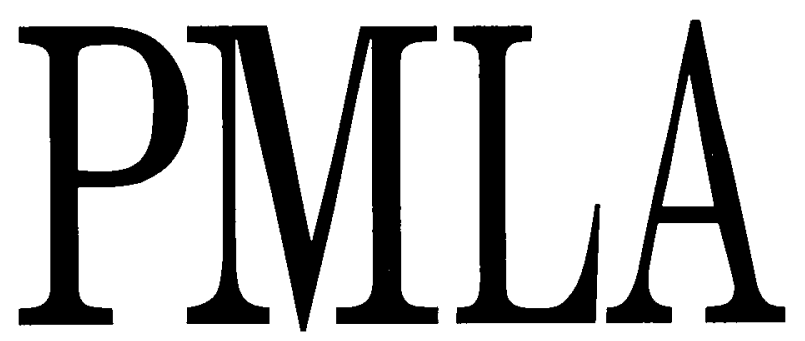

Publications of the

Modern Language Association of America

Volume 110 , Number 2

Published six times a year by the association 


\section{The Modern Language Association of America}

Officers for the Year 1995

For the serm ending 31 December 1996

For the term ending 31 December 1997

For the term ending $3 /$ December 1998

Trustees of Invested Funds
President: SANDER L. GILMAN, Unive'rsity of Chicuge

First Vice President: SANDRA M. GIl.BERT, University of Califomia. Davis Second Vice President: HERBERT LINDENBERGER, Stamford Iniversity

Executive Director: PHYLLIS FRANKLIN

MARTHA BANTA, University of Californid, Los Angeles MARIANNE HIRSCH, Dartmouh College

NAOMI SCHOR, Duke University

NANCY A. WAL KER, Vonderbilt University

LINDA HUTCHEON, Universify of Toronto, Saim George Campus

SUSAN KIRKPATRICK, Universily of Califormia, San Diego

SUSAN RUBIN SULEIMAN, Harvard University

PETER BROOKS, Yale University

ANDREA M. LUNSFORD, Ohio State University: Columbus

SYLVIA MOLLOY, New York University'

SUSAN NOAKES, University of Minnesofa, Twin Cities:

FRANCES SMITH FOSTER, Emony Universiry

PETER UWE HOHENDAHL, Cornell Universily

FRANK TROMMLER, Universiry of Pemsivesmia

CAROLYN G. HEILBRUN, New York, New York

HUGH O'NEILL, New York, New York

MALCOLM B. SMITH (Managing Trustee), New York. New York

PMLA (ISSN 0(030-8129) is published six times a year, in January, March, May, September, October, and November, by the Modern Language Association of America. Membership in the association is open to persons who are professionally interested in the modern languages and literatures. Annual dues, which include subscription to PMLA, are based on members' incomes and are graduated as follows: student members (four years maximum), $\$ 20$; new regular members (first year), $\$ 35$; regular members (income under $\$ 15,000)$, $\$ 25$; regular members (income $\$ 15,000$ - $\$ 20,000$ ), $\$ 40$; regular members (income $\$ 20,000-\$ 30,000)$, $\$ 50$; regular members (income $\$ 30,000-\$ 40,000)$, $\$ 65$, regular members (income $\$ 40,000$ $\$ 50,0(0)$ ). $\$ 75$; regular members (income $\$ 50,000-\$ 60,000$ ), $\$ 85$; regular members (income $\$ 60,000$ )- $\$ 70,000)$, $\$ 95$; regular nembers (income $\$ 70,000-\$ 80,000)$, $\$ 105$; regular members (income over $\$ 80,000$ ), $\$ 125$; foreign members, same as regular members (use the American-dollar equivalent to ascertain the dues catcgory). Membership applications are available on request.

The subscription price of PMLA for libraries and other institutions is $\$ 108$. A subscription including a bound volume at the end of the ycar is $\$ 243$, domestic and foreign. Agents deduct $4 \%$ as their fee. Single copies of the January, March, May, and October issues may be obtained for $\$ 12$ each; the September (Directory) issue for $\$ 50$; the November (Program) issue for $\$ 35$

Issues for the current year are available from the Member and Customer Services Office of the association (212 614-6377). Claims for undelivered issues will be honored if they are received within one year of the publication date; thereafter the single-issue price will be charged.

For information about the availability of back issues, inquire of Periodical Service Company, Germantown, NY 12526; 914 941-4404. Early and current volumes may be obtained on microfilm from University Microfilms, Ann Arbor, MI 48106 . Purchase of current volumes on film is restricted to subscribers of the journal.

The office of publication and editorial offices are located at 10) Astor Place. New York, NY 10003-6981; 212 475-9500.

All communications including notices of changes of address should be sent to the Member and Customer Services Office of the association. If a change of address also involves a change of institutional affiliation, that office should be informed of this fact at the same time.

Second-class postage paid at New York, NY, and at additional mailing office.

(1) 1995 by The Modern Language Association of America. All rights reserved. Printed in the United States of America.

Library of Congress Catalog Card Number 12-32040. United States Postal Service Number 449-660.

POSTMASTER: Send address changes to PMLA, Member and Customer Services Office, Modern Language Association of America, 10 Astor Place, New York, NY 10003-6981. 


\section{Publications of the Modern Language Association}

Publis:hed six times a year Indexes: Vols. 1-50, 1935: 51-60, 1945; 51-79, 1964

Editorial Board

Advisory Committee
Editor: DOMNA C. STANTON, University of Michigan, Ann Arbor Managing Editor: JUDY GOULDING

Assistant Editors: ERIN TROSTLE and ERIC WIRTH Editorial Assistants: JOHN D. GOLBACH and JAMES PONIEWOZIK Advertising Manager and Administrative Assistant: CYNTHIA R. PORT Administrative Assistant: XENI FRAGAKIS

CARLOS J. ALONSO, 1996, Emory University LAWRENCE BUELL, 1996, Harvard University VALERIE D. GREENBERG, 1995, Tulane University COPPELIA KAHN, 1996, Brown University PETER RABINOWITZ, 1995, Hamilton College HERBERT F. TUCKER, 1995, University of Virginia

KWAME ANTHONY APPIAH, 1997, Harvard University NINA BAYM, 1995, University of llinois, Urbana CHARLES BERNHEIMER, 1997, University of Pennsylvania JOHN BEVERLEY, 1996, University of Pittsburgh, Pittsburgh JOSEPH BOONE, 1997, University of Southern California RICHARD J. DELLAMORA, 1995, Champlain College, Trent University ELIN DIAMOND, 1997, Rutgers University, New Brunswick JOANNE F. DIEHL, 1997, University of California, Davis LAURIE EDSON, 1996, San Diego State University GAIL FINNEY, 1995, University of California, Davis SUZANNE FLEISCHMAN, 1995, University of California, Berkeley JANE A. GALLOP, 1995, University of Wisconsin, Milwaukee SUSAN GUBAR, 1997, Indiana University, Bloomington JEAN E. HOWARD, 1997, Columbia University KATHRYN HUME, 1997, Penn State University, University Park LAWRENCE D. KRITZMAN, 1996, Dartmouth College H. MARSHALL LEICESTER, JR., 1997, University of California, Santa Cruz JOSEPH F. LOEWENSTEIN, 1996, Washington University GREGORY L. LUCENTE, 1995, University of Michigan, Ann Arbor STEVEN MAILLOUX, 1996, University of California, Irvine RICHARD MARIUS, 1996, Harvard University MICHAEL MCKEON, 1997, Rutgers University, New Brunswick ANNE MELLOR, 1997, University of California, Los Angeles ADRIENNE MUNICH, 1996, State University of New York, Stony Brook RUTH PERRY, 1995, Massachusetts Institute of Technology SANDY PETREY, 1996, State University of New York, Stony Brook ERIC RENTSCHLER, 1995, University of California, Irvine STEPHANIE SANDLER, 1995, Amherst College DEBORA SHUGER, 1996, University of California, Los Angeles FRANK TROMMLER, 1995, University of Pennsylvania PATRICIA YAEGER, 1996, University of Michigan, Ann Arbor MARGARITA ZAMORA, 1996, University of Wisconsin, Madison 


\section{A Statement of Editorial Policy}

PMLA welcomes essays of interest to those concerned with the study of language and literature. As the publication of a large and heterogeneous association, the journal is receptive to a variety of topics, whether general or specific, and to all scholarly methods and theoretical perspectives. The ideal PMLA essay exemplifies the best of its kind, whatever the kind; addresses a significant problem; draws out clearly the implications of its findings; and engages the attention of its audience through a concise, readable presentation. Manuscripts in languages other than English are acepted for review but must be accompanied by a detailed summary in English (generally of $1,000-1,500$ words) and must be translated into English if they are recommended to the Editorial Board. Articles of fewer than 2,500 words or more than 9,000 words are not considered for publication. The word count includes notes but excludes works-cited lists and translations, which should accompany foreign language quotations. The MLA urges its contributors to be sensitive to the social implications of language and to seek wording free of discriminatory overtones.

Only members of the association may submit articles to $P M L A$. Each article submitted is sent to at least one consultant reader and one member of the Advisory Committee. Artieles recommended by these readers are then sent to the members of the Editorial Board. who meet periodically with the editor to make final decisions. Until a final decision is reached, the author's name is not made known to consultant readers, to members of the Advisory Committee and the Editorial Board, or to the editor. Because the submission of an article simultaneously to more than one refereed journal can result in duplication of the demanding task of reviewing the manuscript, it is PMLA's policy not to review articles that are under consideration by other journals. An article found to have been submitted elsewhere will not be published in PMLA even if it has already been accepted for publiciation by the Editorial Board.

Submissions, prepared according to The MLA Style Manual, should be sent in duplicate and addressed to the Managing Editor, PMLA, Modern Language Association, 10 Astor Place, New York, NY 10003-6981. With each submission please include a self-addressed envelope and enough postage for both copies to be returned. Authors' names should not appear on manuscripts; instead, a cover sheet, with the author's name and address and the title of the article, should accompany each manuscript. Authors should not refer to themselves in the first person in the submitted text or notes if such references would identify them; any necessary references to the author's previous work, for example, should be in the third person.

\section{Criticism in Translation}

MLA members are invited to submit to the PMLA Editorial Board proposals for translations. Articles, as well as chapters or sections of books that can function as independent. units, will be considered. The originals may be in any language. Two types of proposals are welcome: (1) significant scholarship from earlier periods that has not lost its forcefulness and whose retrieval in English in PMLA would be a noteworthy event for a broad body of readers or (2) contemporary work of sufficient weight and potential influence to merit the attention of the field as a whole.

A member who wishes to make a proposal should first ascertain that no previous English translation exists. The proposer should then provide the managing editor with the following materials: (1) a photocopy of the original essay, (2) an extended summary of the entire essay in English, (3) an introductory statement of approximately 1,000 words, prepared in accordance with MLA style, that will be published with the essay if the essay is accepted, (4) information on the copyright status of the original (if the translation is accepted for publication, the proposer will be responsible for obtaining permission to print it). In addition, if the proposer wishes to serve as translator of the essay or to designate a translator (who must also be an MLA member), a 1,000-word sample of the translation should be submitted; otherwise the Editorial Board will select a translator.

The translated essays should normally not exceed PMLA's 9,000-word limit. The Editorial Board will approve or decline the proposals, evaluate the quality of the translations, and cooperate with the proposers and translators. 


\section{Contents}

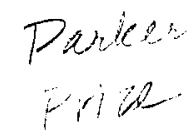

Cover illustration: Rembrandt,

Woman Reading, 1634, etching, state $2(3), 478^{7} \times 315 / 16 "(123 \times 100$ $\mathrm{mm})$. Collection of Museum Het Rembrandthuis, Amsterdam.
Special Topic . . . . . . . . . . . . . . . . . 190

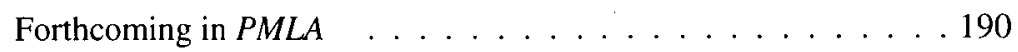

Editor's Column. The Publishability of PMLA Submissions:

Policy and Practice

Ideologies of Lyric: A Problem of Genre in Contemporary

Anglophone Poetics

Mark Jeffreys

The Profession of the Author: Abstraction, Advertising, and

Jane Eyre

Sharon Marcus . . . . . . . . . . . . . . . . . 206

Literary History and Sociology

Gustave Lanson . . . . . . . . . . . . . . . . . 220

T. S. Eliot and the Cultural Divide

David Chinitz . . . . . . . . . . . . . 236

Gödel's Theorem and Postmodern Theory

David Wayne Thomas . . . . . . . . . . . . . . . . . . . . 248

Forum

Contributions by M. E. Grenander, Wayne Booth, Lanae

Hjortsvang Isaacson, John Dowling, James D. Fernández,

John Van Cleve, and Roger J. Craik . . . . . . . . . . . . . 262

Forthcoming Meetings and Conferences of General Interest . . . . 267

Index of Advertisers . . . . . . . . . . . . . . . . 269

Professional Notes and Comment _ . . . . . . . . . . . . . 290

Announcements 290

Journal Notes 296

Meeting of the MLA Executive Council 300

In Memoriam 308

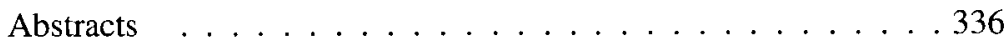

